\title{
Teacher Performance Analysis in the Learning Process
}

\author{
Sri Wahyu ${ }^{1 *}$, Fahmi Rizal2, Nurhasan Syah ${ }^{3}$
}

1,2,3 State University of Padang, Padang, Indonesia

A R T I C L E I N F 0

Article history:

Received 12 December 2020

Received in revised

Form 11 January 2021

Accepted 01 February

2021

Available online 04

February 2021

Keywords:

Teacher Performance,

Learning

Implementation

\begin{abstract}
A B S T R A C T
Educational problems that occur today include the low quality of education at each level of the education unit. It is due to low teacher performance. This study aimed to analyze teacher performance in the learning planning process, learning implementation, and learning evaluation. This research method is carried out using a qualitative approach research method that produces descriptive data in written or spoken words from the teachers that can be observed. The interviewing instruments are interviews, observation, and documentation. Data analysis techniques are used through data reduction, data display, and verification (concluding). Based on this study's findings, it is concluded that the teacher's performance in lesson planning has met the criteria that must be done in learning, learning materials, learning resources, learning media, and assessment of learning outcomes. By making the lesson plan, the teacher has carried out the lesson planning well. The teacher's performance in implementing learning has been carried out well. It can be seen from the learning activities that have been created by the teacher in the classroom. Teacher performance in learning evaluation includes evaluating good learning outcomes by implementing structured remedial and enrichment.
\end{abstract}

\section{Introduction}

Development is a continuous process that covers all aspects of community life, including social, economic, political, and cultural aspects, to improve the nation's citizens (Mulyadin, 2016; Subaryana, 2015). In the development process, the role of education is very strategic. The level of success, Indonesia's national development relies heavily on human resources as national assets optimize and maximizes the development of all its resources (Marzuki \& Basariah, 2017; Suriansyah \& Aslamiah, 2015). These efforts can be made and pursued through education, both through formal education and non-formal education. Education is expected to form quality humans who can utilize, develop, and master Science and Technology (Warsihna, 2016; Wulandari, Sudatha, \& Simamora, 2020). A national paradigm based on Pancasila and the 1945 Constitution must be a rational thinking concept and a pattern in developing national education development policies (Saidi, 2016; Sujana, 2019).

The educational problems currently being faced by the Indonesian people include the low quality of education at each level of the education unit (Suryana, 2020; Yayuk \& Sugiyono, 2019). Research conducted by Suryana states that Indonesia's national education is still faced with various serious challenges in equitable distribution and expansion of access, quality improvement, school structuring, and usually an improvement in education (Suryana, 2017). Currently, there are also issues regarding an inconsistent education system. The government has responded to the complexity of the problems that arise by improving national education quality. There is the procurement of books and learning tools, various training and competency improvements such as Teacher Competency Examination (UKG), Teacher Performance Assessment (PKJ), Teacher Professional Training Education (PLPG), and Teacher Professional Education in Position (PPGJ), and so on, improving educational facilities and infrastructure, and quality improvement in various control indicators. Teacher training that has not contributed much, unsystematic teacher development, low work ethic will lead to sub-optimal teaching performance (Agathi Dian, Kristiantari, \& Ganing, 2015; Supriyo, 2015). As a result, these teachers do not show work motivation and teaching performance that is not optimal in carrying out their duties and obligations as teachers. The mastery level that is not achieved, the error is placed on the non-student teaching staff, which can be seen in the average UAN score. This problem was found in vocational schools, SMK Negeri 1 Sutera, Pesisir Selatan Regency. The average UAN score in the 2018/2019 academic year for the South Coastal District Vocational School, SMK Negeri 1 Sutera received the lowest score of 5.24. As stated by Bloom, if the specified level of mastery is not achieved, the error is placed on non-student teaching staff 
(Anderson \& Krathwohl, 2010). Students' learning outcomes are used to determine the level of student success, determine graduation, and as teacher feedback about learning according to the educational goals of SMK Negeri 1 Sutera, Pesisir Selatan Regency in particular.

Education is said to be of high quality if there is an effective and efficient learning process by involving all educational components such as including learning objectives, teachers, students, learning materials, learning methods, tools, and learning resources (Herayanti, Habibi, \& Fuaddunazmi, 2017; Puspitasari, 2018; Widodo \& Kartikasari, 2017). Therefore it is necessary to improve the quality of education. Improving the quality of education is determined by the readiness of human resources involved in the education process. One of the factors that affect education quality is the teaching staff or teachers (Surahman \& Mukminan, 2017; Wahyono, Husamah, \& Budi, 2020). It implies that improving the quality of education must start with teachers and other education personnel, in optimizing the teaching performance of teachers, in carrying out their duties and jobs, mobilizing, motivating, inviting, directing, advising, guiding, ordering, prohibiting, and even giving sanctions, and fostering to achieve school performance effectively and efficiently (Cicilia \& Nursalim, 2019; Trianingsih, 2016). As formal institutions, schools certainly strive to create competent graduates by making various improvement efforts in all fields. As one of the main components in the learning process, the teacher is expected to create such conditions to learn actively.

One of the government's efforts to improve education quality is by holding and implementing various programs to improve teacher performance quality. The programs held include upgrading for teachers, seminars and workshops, in-service scholarships, and the presence of Subject Teacher Deliberation Groups (MGMP). The existence of this MGMP is expected to improve the quality of the subject teachers. In the MGMP it is also possible to exchange opinions and experiences between subject teachers who can lead to joint problem-solving. Competent teachers will be better able to create an effective, fun learning environment and better manage their classes (Hamalik, 2015; Supriyo, 2015). It means that a large responsibility lies with the teacher as the learning manager in delivering material and overcoming students' boredom with the subject. Teachers must have and develop various competencies as professional and high-performing teachers to improve student learning outcomes.

The teacher is the component that most influences the creation of quality education processes and outcomes. Therefore, any improvement efforts made to improve the quality of education will not make a significant contribution without the support of professional and qualified teachers (Agathi Dian et al., 2015; Suparlan, 2005). The teacher is the key person in the classroom, so that the teacher has a vital and fundamental role in guiding, directing, and educating students in the learning process (Rahmawati, 2018; Werang, 2015). Teachers' role is very important so that teachers' existence will not be replaced by anyone or anything, even with sophisticated technology. Educational tools and media, infrastructure, multimedia, and technology are only media or tools used as teachers' companions (Puspitorini, Subali, \& Jumadi, 2014; Rosidah, 2016). It is because human elements such as attitudes, systems, values, feelings, motivations, habits, etc., which are expected to be the result of the teaching process, cannot be achieved through tools or technology created by humans to help and facilitate their lives.

Teacher performance in planning and implementing learning is a major factor in achieving teaching goals. The learning process's mastery is very heavy to teachers' duties and responsibilities as teachers and educators (Sarimaya, 2008; Yulianingsih \& Sobandi, 2017). Teacher performance is the performance performed by the teacher in carrying out their duties. The quality of teacher performance strongly influences the quality of the teaching and learning process. The quality of teacher performance will greatly determine a lesson's success, which will affect the quality of educational outcomes (Junianto \& Wagiran, 2013; Soetjipto \& Kosasi, 1994). The teacher is the party who has the most direct contact with students in the education or learning process at school. This attitude is also shown by a sense of responsibility in preparing all teaching equipment before carrying out the learning process, carrying out learning optimally, and carrying out evaluations as well as possible.

This study analyzes SMK Negeri 1 Sutera's performance in the learning planning process, learning implementation, and learning evaluation. It is hoped that the teacher can guide, direct, and educate students in the learning process so that the learning and educational objectives can be maximally achieved.

\section{Methods}

According to Bogdan and Taylor, the method used in this research is a qualitative approach. Qualitative methods are research procedures that produce descriptive data in written or spoken words from people and observable behavior. This approach is directed towards the setting and the individual in a holistic manner. In this study, what will be observed is teachers' performance in learning at SMK Negeri 
1 Sutera, Pesisir Selatan Regency, which includes learning planning, learning process, and learning evaluation. Using qualitative methods, the data obtained will be more complete, deeper, credible, and meaningful to achieve the research objectives. This study uses data collection techniques with in-depth interviews, observation, and documentation. The technique used in analyzing the data is interactive analysis. The interaction of the components of data reduction and data display is carried out simultaneously with the data collection process. After the data is collected, the three components of the analysis (data reduction, data display, conclusion, or verification) interact.

\section{Result and Discussion}

The study results have shown that the teacher's performance in lesson planning has been good with a complete learning tool. Learning planning involves selecting, determining, and developing methods based on existing teaching conditions (Fitri, Saparahayuningsih, \& Agustriana, 2017; Qasim \& Maskiah, 2016). Learning planning answers what questions will be done during the learning process. Learning planning is a decision-making process resulting from thinking rationally about certain learning goals and objectives by utilizing all existing potential and resources (Pratiwi \& Rahmah, 2018; Sutarman \& Asih, 2016). Two important points to consider in the planning of learning by every educator. First, preparation in planning learning activities. This activity includes recognizing the conditions surrounding students, understanding students' characteristics, understanding the learning styles and abilities of students, and having the competence as professional educators. Second, teaching planning activities include developing a syllabus and compiling a Learning Implementation Plan (Khoeriyah \& Mawardi, 2018; Wijaya, 2019). Learning planning is very important because of the guidelines and benchmarks for learning, regarding the importance of learning planning in the learning process, the results of previous research that focused on the suitability of lesson plans and the learning process (Khoeriyah \& Mawardi, 2018; Mastra, 2019). In teachers' professional competence, learning planning performance is one of the things that support the teacher before starting learning. Learning planning is a process indicator that can be objectively used as an indicator to measure teacher performance. Learning planning includes goals, objectives, methods, use of media, and processes. Learning objectives provide direction about the abilities that will be achieved through learning (Sujana, 2019). When compiling a lesson plan, the teacher will: (1) make the syllabus as a guide in designing the lesson plan (RPP), (2) the teacher must have four teacher competencies, especially pedagogical competencies, one of the abilities in developing and compiling lesson plans, and ( 3) compile a Learning Implementation Plan (RPP) following the applicable curriculum.

Learning planning is the initial function of learning management activities for an active and efficient purpose. Teacher performance in learning planning includes formulating learning objectives, preparing learning materials, learning resources, preparing learning media, planning learning activity scenarios, and planning learning outcome assessments (Mastra, 2019; Sari, 2019). In general, learning planning aims to direct and guide teacher's and students' activities in the learning process. The success of a learning process is determined by careful planning. Planning is done well, then half of the success can be achieved. The other half lies in implementation (Fitri et al., 2017; Gafur, 2012). The syllabus is a set of plans and arrangements for implementing learning and assessment, which are arranged systematically containing interrelated components to achieve mastery of basic competencies. The syllabus used by the teacher, the syllabus from the education office, is then developed by the school MGMP or holding workshops tailored to school conditions. The learning objectives to be achieved are adjusted to students and schools' conditions so that each school has different learning objectives. The learning resources used by the teacher are not focused on just one book but also relevant books. Teacher also follow the latest developments and associate with material obtained from electronic media and newspapers. Almost all students themselves have worksheets as handbooks and textbooks are provided at school. The media used by the teacher aims to make it easier to convey material and that students understand the material they are learning. The media to be used is adjusted to school conditions.

The teacher's main task is to make learning scenarios or lesson plans because RPP is a teaching plan that is realized from students' learning experiences determined at the stage of determining the learning experience. RPP is a learning activity plan that includes all activities (Wijaya, 2019; Wikanengsih, Nofiyanti, \& Permana, 2015). With the RPP, teachers reference teaching to not deviate from the goals to be achieved. The difference is in the core activities that carry out exploration, elaboration, confirmation, followed by face to face, structured assignments, unstructured independent activities. Exploring is an effort to find new information. What needs to be considered in exploration is introducing new material, linking new material with previous material that students have obtained from this material (Meidianawaty, Widyandana, \& Kristina, 2016; Salmiati, 2017). Elaboration is a negotiation to achieve new knowledge that needs to be considered in this elaboration, involving students actively understanding 
and interpreting new material in solving problems, linking material with events that will occur. Confirmation is the processing of knowledge into values, attitudes, and behavior. What needs to be considered in confirmation is to encourage students to apply the concepts learned in everyday life and build students' attitudes and behavior in teaching and learning activities. A. Cycle 1 consists of several stages: (1) Planning, (2) Implementation, (3) Observation and Evaluation, and (4) Reflection. 1. Planning is the first step taken by the author when he will initiate action. In this study, the authors took a plan to take action to provide continuous guidance to teachers to compile a lesson plan (RPP).

The teacher has developed RPP on aspects of syllabus studies, aspects of material identification, aspects of learning objectives, aspects of learning activities, aspects of models, methods and strategies, aspects of assessment, and aspects of time allocation (Cicilia \& Nursalim, 2019; Cintia, Kristin, \& Anugraheni, 2018). RPP analysis found several shortages of teachers in preparing lesson plans. The deficiency lies in the allocation of time, learning resources, and assessment. The time allocation is not included in full, the number of meetings, and the length of learning activities. Learning sources are not fully stated; only written textbooks were mentioning the book title and publisher only. SMK / MAK teachers in preparing learning tools must pay attention to the distribution of time allocations according to Perdirjen No.7 of 2018 concerning the SMK / MAK curriculum structure.

The research results have shown that the teacher's performance in the learning process has reached a better direction but still lacks teaching methods. Teacher performance in carrying out the learning process is described into four components, pre-learning, opening lessons, core learning, and closing (Mukhtar, 2015; Yulianingsih \& Sobandi, 2017). The teacher opens the lesson before delivering the material. The standard procedure in opening lessons is apperception such as saying greetings, absent, reminding the previous material with questions and answers then entering the material by conveying the objectives first. The learning process is at the core of the teacher's overall education process as the main message holder. The learning process is a process that contains a series of actions by teachers and students based on reciprocal relationships that take place in educational situations to achieve certain goals. Teacher performance in the learning process includes; a) opening learning, b) carrying out learning activities, c) methods used in delivering material, d) utilizing sources or media, e) active students in learning (Junianto \& Wagiran, 2013; Putri \& Imaniyati, 2017). The learning method is also adapted to the subject matter provided. The subject matter involving a lot of practice will be dominated by the practicum method to accept the lesson easily. Teachers carry out the development of subject matter in various ways, including providing additional subject matter outside school hours and inviting students to enrich their insights and knowledge from textbooks and take advantage of current technology to enrich information and knowledge. Teachers also care about students' success, especially those who will end school, by providing national exam questions and answer methods so that students are ready and able to take national exams.

In the core learning activity, some teachers explain what material will be delivered. Teachers make students active in learning. The method used is an attractive teaching method and the media used. The learning method is very important because it delivers information or material to students (Amri, 2018; Puspitasari, 2018). Without a good method, learning will be less successful in achieving learning objectives. The choice of method must be adjusted to the material and also the characteristics of students. At the same time, the media is a means or tool to convey material so that it is easier for students to understand, and the use of media depends on the material to be delivered (Qumillaila, Susanti, \& Zulfiani, 2017; Sukmanasa, Windiyani , \& Novita, 2017). The method used by the teachers of SMK Negeri 1 Sutera, Pesisir Selatan Regency is not only conventional lectures but also uses varied lectures that vary the lecture method with other methods such as question and answer, discussion, and assignments. The lecture method is used to deliver the material. The question and answer method are used to determine the level of understanding of students.

The method provides students opportunities to be more active in learning because after discussion, students will be asked to come forward for presentations (Khoeriyah \& Mawardi, 2018). The assignment is an activity for each individual to motivate students to learn. By varying the methods, students do not feel bored with the monotonous impression of the subject matter. Students can also be actively involved in teaching and learning activities. Students are more active with interesting methods, but the teacher's media will make students more interested in learning (Maqfiroh, Khutobah, \& Budyawati, 2020; Yusnia, 2019). The facilities in schools that are often used by students are libraries and the internet. Other means such as LCD or OHP have not been maximized because they are used interchangeably with other subjects. The facilities provided by schools are still very limited, but teachers can make optimal use of them.

The study results show that teacher performance in learning evaluation has been carried out even though it is not perfect. It indicates that teacher performance in managing the learning process can be 
used as a predictor of learning outcomes. Teacher competency standards measure educational programs' achievement, planning of a basic education program including the curriculum and its implementation, procurement and capacity building of teachers, education management, and overall education reform. Teacher performance in evaluating learning includes a) evaluating learning outcomes, b) implementing remedial and enrichment.

There are 3 types of subject assessment, including cognitive, psychomotor, and affective. The cognitive assessment consists of daily tests, independent assignments, structured assignments, and midterm tests. The methods used in the cognitive assessment are objective questions and essays. Psychomotor assessment is a form of assessment of the work of students' practice. At the same time, affective assessment is seen from students' attitudes in the following lessons, when students are in discussion or are being asked and answered. Evaluation is carried out if the basic competencies and learning objectives have been achieved and sees students' readiness in carrying out evaluations and students' understanding of the subject matter (Triwiyanto, 2015; Yusuf, 2015).

The evaluation stage is the final stage carried out by the teacher at SMK Negeri 1 Sutera, Pesisir Selatan Regency to determine the extent of the ability of students in understanding the subjects that have been given in the learning process in the classroom by giving individual assignments, group assignments and tests to determine the abilities achieved students during class lessons (Nugraha, 2017; Nurkancana \& Sunartana, 1992) Individual assignments and group assignments are given to students after learning. The individual task given is to work on the Student Worksheet (LKPD) to remember the material presented. In contrast, the group assignment is given so that students can directly participate in the community. After this group assignment is done, students are asked to discuss a good learning process in front of the class. They have a quality management system, which is supported by professional human resources. From the results, it can also be seen that teachers' teaching ability has a positive relationship with teacher performance and student learning outcomes and teacher performance and has a positive relationship with student learning outcomes in school. The teacher gives daily tests if the material or goals have been achieved. Daily test in the form of a written test and essay. It is intended to train students to remember the material presented and see each student's abilities from students' answers.

Meanwhile, for midterm and end-of-semester tests, an objective test was used, multiple-choice questions. The teacher increases student activity in further learning activities by giving group assignments. Teachers take the time to guide students whose scores have not reached the KKM score and develop teaching materials for further learning activities. Teachers actively consult with parents about the progress and development of potential students.

The teacher implements a follow-up program after conducting an evaluation, remedial (improvement), and enrichment. A remedial program is a special form of teaching given to a person or several students who experience learning difficulties and low scores. An enrichment program is a form of special teaching given to students who are very fast in learning and get high scores. Remedials (improvements) are carried out by repeating evaluations to students who score below the KKM. In preparation for implementation, the teacher must take several remedial actions, including implementing learning difficulties (Lukum \& Astin., 2015; Salamah, 2019). The next step in the diagnosis of learning difficulties is to localize the location of learning difficulties. After that, it is only known which students have completed the SKL or not, and the teacher can determine whether there is a remedial. Students who carry out enrichment activities have maximum results, and students also get a new experience in studying the material and developing their knowledge. The enrichment has not been fully implemented due to limited time in the learning process. Enrichments are provided so that students can understand more about the related material. The enrichment given is in the form of questions with a higher level of difficulty or reading material afterward. Enrichment is given as an added value to students. Assignments given are in the form of papers obtained from the internet or newspapers related to the subject matter.

This study has positive implications for improving teacher performance in learning. The creation of good teacher performance will improve the quality of education. In carrying out its role, the teacher must master the learning material but has a good personality, choose suitable methods, models, and learning media to be applied to understand easily and not get bored in the learning process. An increase in teacher performance through educational supervision, including improvements in learning plans, implementing learning, assessing learning achievement, and carrying out follow-up assessments of student learning achievement (Chasanah, 2020). There is a positive influence between teacher work motivation on teacher performance (Sari, 2019). It shows that increasing competence, teacher work motivation and incentives, and teacher performance will also increase. 


\section{Conclusion}

The teacher's performance in learning planning has met the learning criteria according to the applicable curriculum. The SMK Negeri 1 Sutera teachers have included learning objectives, learning materials and learning resources, learning media, and assessing learning outcomes. The teacher's performance in implementing learning has been carried out well. Evaluation of learning with remedial and enrichment has been going well. Still, the enrichment was not fully implemented from the curriculum spectrum's basic competencies due to time constraints.

\section{References}

Agathi Dian, I. A. A., Kristiantari, R. M. G., \& Ganing, N. (2015). Guru Terhadap Hasil Belajar Pengetahuan Bahasa Indonesia ( Keterampilan Membaca ) Tema Cita-Citaku Pada Siswa Kelas IV SD Desa Peguyangan. Mimbar PGSD Undiksha, https://doi.org/http://dx.doi.org/10.23887/jjpgsd.v3i1.5172.

Amri, N. A. (2018). Pengaruh Metode Bermain Peran Terhadap Kemampuan Komunikasi (Bahasa Ekspresif) Anak Taman Kanak-Kanak Raudhatul Athfal Alauddin Makassar. Jurnal Ilmu $\begin{array}{lllll}\text { Pendidikan, Keguruan, } & \text { Dan }\end{array}$ https://doi.org/10.26858/pembelajar.v1i2.4864.

Anderson, L.W dan Krathwohl, D. R. 2010. (2010). Kerangka Landasan untuk Pembelajaran, Pengajaran dan Asesmen (Revisi Taksonomi Pendidikan Bloom). Pustaka Pelajar.

Chasanah. (2020). Peningkatan Kinerja Guru Dalam Pembelajaran Di Kelas Melalui Supervisi Edukatif Kolaboratif Secara Periodik DI SD Negeri Jogoyitnan Kabupaten Wonosobo 2019/2020. Jurnal Literasiologi, 3(3). https://doi.org/https://doi.org/10.47783/literasiologi.v3i3.101.

Cicilia, Y., \& Nursalim. (2019). Gaya dan Strategi Belajar. Jurnal Ilmu Pendidikan, 1(1), 222-232.

Cintia, N. I., Kristin, F., \& Anugraheni, I. (2018). Penerapan Model Pembelajaran Discovery Learning Untuk Meningkatkan Kemampuan Berpikir Kreatif Dan Hasil Belajar Siswa. Perspektif Ilmu Pendidikan. https://doi.org/10.21009/pip.321.8.

Fitri, Saparahayuningsih, \& Agustriana. (2017). Perencanaan Pembelajaran Kurikulum 2013 Pendidikan Anak Usia Dini. Jurnal Ilmiah Potensia, 2(1). https://doi.org/https://doi.org/10.33369/jip.2.1.113.

Gafur, A. (2012). Desain Pembelajaran Konsep, Model, dan Aplikasinya dalam Perencanaan Pelaksanaan Pembelajaran. Penerbit Ombak.

Hamalik, O. (2015). Proses Belajar Mengajar. Bumi Aksara.

Herayanti, L., Habibi, H., \& Fuaddunazmi, M. (2017). Pengembangan Media Pembelajaran Berbasis Moodle pada Matakuliah Fisika Dasar. Jurnal Cakrawala Pendidikan, 36(2), 210-219. https://doi.org/10.21831/cp.v36i2.13077.

Junianto, D., \& Wagiran, W. (2013). Pengaruh kinerja mengajar guru, keterlibatan orang tua, aktualisasi diri dan motivasi berprestasi terhadap prestasi. Jurnal Pendidikan Vokasi, 3(3), 307-319. https://doi.org/10.21831/jpv.v3i3.1845.

Khoeriyah, N., \& Mawardi, M. (2018). Penerapan Desain Pembelajaran Tematik Integratif Alternatif Berbasis Kearifan Lokal untuk Meningkatkan Hasil dan Kebermaknaan Belajar. Mimbar Sekolah Dasar, 5(2), 63. https://doi.org/10.17509/mimbar-sd.v5i2.11444.

Lukum, \& Astin. (2015). Evaluasi Program Pembelajarn IPA SMP Menggunakan Model Contenance Stake.

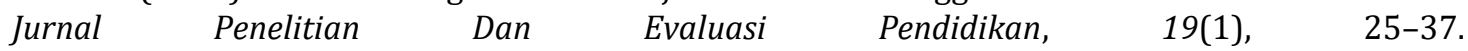
https://doi.org/https://doi.org/10.21831/pep.v19i1.4552.

Maqfiroh, Khutobah, \& Budyawati. (2020). Pengembangan Media MOTIF (Monopoli Edukatif) dalam Pembelajaran berbasis Multiple intelligence. Cakrawala Dini: Jurnal Pendidikan Anak Usia Dini, 11(1), 64-74. Retrieved from https://ejournal.upi.edu/index.php/cakrawaladini/article/view/24230/12062.

Marzuki, \& Basariah. (2017). The Influence Of Problem-Based Learning And Project Citizen Model In The 
Civic Education Learning On Student'scritical Thinking Ability And Self Discipline. Cakrawala Pendidikan, 6(3), 382-400. from https://journal.uny.ac.id/index.php/cp/article/view/14675/pdf.

Mastra, I. N. (2019). Peningkatan Kinerja Guru Dalam Penyusunan Rencana Pelaksanaan Pembelajaran (RPP) Melalui Pendampingan Klasikal Dan Individual Di SD Negeri 26 Ampenan Semester SAtu Tahun Pelajaran 2017/2018. Jurnal Ilmiah Mandala Education, 5(2). https://doi.org/http://dx.doi.org/10.36312/jime.v5i2.755.

Meidianawaty, Widyandana, \& Kristina. (2016). Eksplorasi Permasalahan Dalam Implementasi Community-Based Education Di Fakultas Kedokteran. Jurnal Penelitian Dan Evaluasi Pendidikan, 20(1). https://doi.org/https://doi.org/10.21831/pep.v20i1.7169.

Mukhtar. (2015). Strategi Kepala Sekolah Dalam Meningkatkan Kinerja Guru Pada Smp Negeri Di Kecamatan Masjid Raya Kabupaten Aceh Besar. Jurnal Magister Administrasi Pendidikan, 3(3). Retrieved from http://www.jurnal.unsyiah.ac.id/JAP/article/view/2873/2734.

Mulyadin. (2016). Implementasi Kebijakan Pembelajaran Tematik Terpadu Kurikulum 2013 Di SDN Kauman 1 Malang Dan Sd Muhammadiyah 1 Malang. Jurnal Pendidikan Edutama, 3(2), 31 - 48. https://doi.org/http://dx.doi.org/10.30734/jpe.v3i2.35.

Nugraha, R. (2017). Evaluasi Penerapan Standar Penilaian Kurikulum 2013 Pada Kelas 4 Sekolah Dasar di Kecamatan Jambu. Jurnal Sekolah (JS), 2. https://doi.org/https://doi.org/10.24114/js.v2i1.9925.

Nurkancana, \& Sunartana. (1992). Evaluasi Hasil Belajar. Surabaya: Usaha Nasional.

Pratiwi, \& Rahmah. (2018). Implementasi Model Pembelajaran Sentra Main Peran untuk Mengembangkan Motorik Halus AUD. Jurnal Ilmiah Tumbuh Kembang Anak Usia Dini, 3(3). https://doi.org/https://doi.org/10.14421/jga.2018.181-190.

Puspitasari. (2018). Metode Pembelajaran Bermain Peran Pada Pembelajaran Bahasa Indonesia. Jurnal Cakrawala Pendas, $I(1), \quad$ 55-64. https://doi.org/https://www.researchgate.net/deref/http\%3A\%2F\%2Fdx.doi.org\%2F10.31949 \%2Fjcp.v1i1.347.

Puspitorini, Subali, \& Jumadi. (2014). Penggunaan Media Komik Dalam Pembelajaran IPA Untuk Meningkatkan Motivasi Dan Hasil Belajar Kognitif Dan Afektif. Cakrawala Pendidikan, 33(3), 413420. Retrieved from https://journal.uny.ac.id/index.php/cp/article/view/2385/pdf.

Putri, \& Imaniyati. (2017). Pengembangan Profesi Guru Dalam Meningkatkan Kinerja Guru. Jurnal Manajemen Pendidikan Perkantoran, 2(2). https://doi.org/https://doi.org/10.17509/jpm.v2i2.8109.

Qasim, \& Maskiah. (2016). Perencanaan Pengajaran Dalam Kegiatan Pembelajaan. Jurnal Diskursus Islam, $4(3)$.

Qumillaila, Susanti, \& Zulfiani. (2017). Pengembangan Augmented Reality Versi Android Sebagai Media Pembelajaran Sistem Ekskresi Manusia. Cakrawala Pendidikan, 34(1), 57-69. Retrieved from https://journal.uny.ac.id/index.php/cp/article/view/9786/pdf. \%0A.

Rahmawati, A. (2018). Identifikasi Masalah yang Dihadapi Guru dalam Penerapan Kurikulum 2013. Indonesian Journal of Primary Education, 2(1), 114-123. https://doi.org/https://doi.org/10.17509/ijpe.v2i1.14227.

Rosidah, A. (2016). Penerapan Media Pembelajaran Visual Untuk Meningkatkan Pemahaman Konsep Siswa Pada Mata Pelajaran Ips. Jurnal Cakrawala Pendas, 2(2). https://doi.org/10.31949/jcp.v2i2.499.

Saidi, S. (2016). Perbedaan Prestasi Belajar Siswa Yang Mengikuti Bimbingan Belajar dan Yang Tidak Mengikuti Bimbingan Belajar Siswa Kelas XII IPS Mata Pelajaran Ekonomi SMA Sinar Pancasila Balikpapan. Jurnal Intelegensia, 2(1). https://doi.org/10.1017/CB09781107415324.004.

Salamah, I. (2019). Evaluasi Usability Website Polsri Dengan Menggunakan System Usability Scale. Janapati Jurnal Nasional Pendidikan Teknik Informatika, 8(3). https://doi.org/http://dx.doi.org/10.23887/janapati.v8i3.17311.

Salmiati. (2017). Meningkatkan Kegiatan Eksplorasi Anak Melalui Media Lingkungan Sekitar Di Kelompok 
B Home Schooling Al Gifari Kota Kendari. Jurnal Smart PAUD, 1(1). https://doi.org/http://dx.doi.org/10.36709/jspaud.v1i1.3515.

Sari, H. P. (2019). Pengaruh Kompetensi, Motivasi Kerja Dan Insentif Terhadap Kinerja Guru SMA. Perspektif Imu Pendidikan., 33(1). https://doi.org/https://doi.org/10.21009/PIP.331.8.

Sarimaya, F. (2008). Sertifikasi Guru: Apa, Mengapa, Bagaimana. Yrama Widya.

Soetjipto, \& Kosasi, R. (1994). Profesi Keguruan. Direktorat Jendral Pendidikan Tinggi Departemen Pendidikan dan Kebudayaan.

Subaryana. (2015). Konsep Diri dan Prestasi Belajar. Jurnal Dinamika Pendidikan Dasar, 7(2), 21-30. https://doi.org/http://dx.doi.org/10.30595/dinamika.v7i2.929.

Sujana, I. W. C. (2019). Fungsi Dan Tujuan Pendidikan Indonesia. Adi Widya: Jurnal Pendidikan Dasar, 4(1), 29. https://doi.org/10.25078/aw.v4i1.927.

Sukmanasa, Windiyani, \& Novita. (2017). Pengembangan Media Pembelajaran Komik Digital Pada Mata Pelajaran Ilmu Pengetahuan Sosial Bagi Siswa Kelas V Sekolah Dasar Di Kota Bogor. Jurnal Pendidikan Sekolah Dasar, 3(2). https://doi.org/https://doi.org/10.30870/jpsd.v3i2.2138.

Suparlan. (2005). Menjadi Guru Efektif. Yogyakarta: Adicita Karya Nusa.

Supriyo. (2015). Motivasi Kerja Guru Smp Negeridi Kota Semarang. Cakrawala Pendidikan, 34(1). Retrieved from https://journal.uny.ac.id/index.php/cp/article/view/4173/pdf.

Surahman, E., \& Mukminan. (2017). Peran guru IPS sebagai pendidik dan pengajar dalam meningkatkan sikap sosial dan tanggung jawab sosial siswa SMP. Harmoni Sosial: Jurnal Pendidikan IPS, 4(1), 113. https://doi.org/https://doi.org/10.21831/hsjpi.v4i1.8660.

Suriansyah, \& Aslamiah. (2015). Strategi Kepemimpinan Kepala Sekolah, Guru, Orang Tua, Dan Masyarakat Dalam Membentuk Karakter Siswa. Cakrawala Pendidikan, 34(2). Retrieved from https://journal.uny.ac.id/index.php/cp/article/view/4828/4180.

Suryana. (2020). Permasalahan Mutu Pendidikan Dalam Perspektif Pembangunan Indonesia. Jurnal Edukasi, 14(1). https://doi.org/https://doi.org/10.15294/edukasi.v14i1.971

Suryana, S. (2017). Permasalahan Mutu Pendidikan Dalam Perspektif Pembangunan Pendidikan. Jurnal Edukasi, 2(1). Retrieved from https://journal.unnes.ac.id/nju/index.php/edukasi/article/view/971.

Sutarman, \& Asih. (2016). Manajemen Pendidikan Anak Usia Dini (Filosofi, Konsep, Prinsip dan Aplikasi). Pustaka Setia.

Trianingsih, R. (2016). Pengantar Praktik Mendidik Anak Usia Sekolah Dasar. Al Ibtida: Jurnal Pendidikan Guru MI, 3(2), 197. https://doi.org/10.24235/al.ibtida.snj.v3i2.880.

Triwiyanto, T. (2015). Pelaksanaan Monitoring, Evaluasi, Danpelaporan Untuk Penilaian Kinerja Manajerial Kepala Sekolah. Cakrawala Pendidikan, 34(1). Retrieved from https://journal.uny.ac.id/index.php/cp/article/view/4177/pdf.

Wahyono, P., Husamah, H., \& Budi, A. S. (2020). Guru profesional di masa pandemi COVID-19: Review implementasi, tantangan, dan solusi pembelajaran daring. Jurnal Pendidikan Profesi Guru, 1(1), 51-65. https://doi.org/https://doi.org/10.22219/jppg.v1i1.12462.

Warsihna, J. (2016). Meningkatkan Literasi Membaca dan Menulis dengan Teknologi Informasi dan Komunikasi. Kwangsan, 4(2), 67 - 80. https://doi.org/Meningkatkan Literasi Membaca dan Menulis dengan Teknologi Informasi dan Komunikasi.

Werang, B. R. (2015). Pengaruh Kepemimpinan Transformasional Kepala Sekolah, Moral Kerja Guru, Dan Kepuasan Kerja Terhadap Kinerja Guru SDN Di Kota Merauke. Cakrawala Pendidikan, 38(1). Retrieved from https://journal.uny.ac.id/index.php/cp/article/view/1869/pdf.

Widodo, S., \& Kartikasari, K. (2017). Pembelajaran Pemecahan Masalah Matematis Siswa Sekolah Dasar Dengan Model Creative Problem Solving (Cps). Prisma, 6(1). https://doi.org/10.35194/jp.v6i1.28.

Wijaya, T. (2019). Panduan Praktis Menyusun silabus, RPP, dan Penilaian Hasil Belajar. PT. HUTA PARHAPURAN. 
Wikanengsih, Nofiyanti, \& Permana. (2015). Analisis Rencana Pelaksanaan Pembelajaran (Rpp) Mata Pelajaran Bahasa Indonesia (Studi Terhadap Rpp Yang Disusun Guru Bahasa Indonesia Tingkat SMP Di Kota Cimahi. Jurnal Ilmiah P2M STKIP Siliwangi P2M STKIP Siliwangi, 2(1). https://doi.org/https://doi.org/10.22460/p2m.v2i1p106-119.170.

Wulandari, Sudatha, \& Simamora. (2020). Pengembangan Pembelajaran Blended Pada Mata Kuliah Ahara Yoga Semester II di IHDN Denpasar. Jurnal Edutech Undiksha, 8(1), 1-15. https://doi.org/http://dx.doi.org/10.23887/jeu.v8i1.26459.

Yayuk, S., \& Sugiyono, S. (2019). Pengaruh kepemimpinan kepala sekolah dan biaya pendidikan terhadap kualitas proses belajar mengajar dan dampaknya dengan kompetensi lulusan SMK di kabupaten Gunungkidul. Jurnal Akuntabilitas Manajemen Pendidikan, 7(1), 84-96. https://doi.org/10.21831/amp.v7i1.23758.

Yulianingsih, \& Sobandi. (2017). Kinerja Mengajar Guru Sebagai Faktor Determinan Prestasi Belajar Siswa. Mamper Jurnal Manajemen Perkantoran, 2(2). https://doi.org/https://doi.org/10.17509/jpm.v2i2.8105.

Yusnia, Y. (2019). Penggunaan Media Video Scribe Dalam Pembelajaran Literasi Sains Untuk Mahasiswa PGPAUD. Cakrawala Dini: Jurnal Pendidikan Anak Usia Dini, 10(1), 71-75.

Yusuf, M. (2015). Asessmen dan Evaluasi Pendidikan. Prenadamedia Group. 